\title{
OUR LUCKY LOUISIANA PURCHASE
}

\section{By EDwiN MULLER*}

The Louisiana Purchase made a great continental power out of a struggling third-class nation. Yet it was not the result of planning or farseeing statesmanship. It happened by an unexpected lucky chance, clinched for us by the bold decision of a man whom history has almost forgotten. Nobody would have suspected that Robert Livingston was a man for bold action. He was of the cautious, painstaking sort. His work in congress was diligent and honest but never spectacular.

In 1801 Thomas Jefferson appointed him Minister to France. He was sent primarily to collect a bill. During the Napoleonic wars the French had attacked our vessels and confiscated the cargos. But relations had improved, and it seemed possible that we might recover some of the damage sustained by our shipowners. That was livingston's job.

He settled himself in a modest apartment overlooking a garden in the Rue Chaussée d'Antin and tried to get down to business. The man with whom he had to deal was Napoleon's foreign minister, the smooth and wily Talleyrand. He was too slippery for the plodding American. Whenever Livingston tried to pin him down, Talleyrand somehow eluded him. Livingston was further handicapped by having only an imperfect command of French. No progress was made as the months went by. Livingston grew discouraged and wrote to Jefferson: "I see little use for a minister here."

But presently a situation developed which was far more important than the collection of claims. To understand it we must turn from Paris to the backwoods of North America. Already half a million Americans were living

* This factual article by Edwin Muller appeared as the current historical offering in "Vignettes of History" in the July 1944 number of the Reader's Digest, ing in "Vignettes of that publication. Embracing and is reprinted in THE ANNALS with permission or that publication. Em ire of the the great midwest section of our country, it became a part of "our empire of the West," through the "accidents of history, Napoleon's ambitions for world con- 
west of the Alleghenies. There were settled communities, and life in them depended on trade with the rest of the nation, with the rest of the world. Overland routes were as yet undeveloped. But nature had provided the ideal highway for commerce-the muddy ohio and the broad Mississippi. Old Man River was the life line of the west.

All the river was free to the settlers-except its mouth. Spain not only owned the vast Louisiana Territory beyond the river, she also stood astride the river itself at New Orleans.

From Madrid the weak Don Carlos IV ruled, on paper, the mightiest empire on earth-but nobody minded him much. The westerners had no difficulty bringing him to terms as to the Mississippi's mouth. There was established at New Orleans what was known as the "right of deposit." Freight coming down the river was unloaded from the flatboats and stored in warehouses until it could be put aboard ocean-going ships.

During the closing years of the 18th century the traffic grew steadily. There were barrels of flour, bales of cotton, tobacco, hams, lead, wagon wheels, beef, furs, skins-much of it destined for overseas.

So the west grew and prospered. So it might have gone on growing-except for one man.

Napoleon, at the turn of the century, dominated Europe with his armies. Only England still defied him. He decided on a grand shift in his strategy of world conquest. He made a truce with England and turned his attention to the New World. First he forced Don Carlos to cede to him the whole of Louisiana Territory. As a base for his operations against the New World, he chose the French colony of Santo Domingo. France's hold there had been weakened by the revolt of the black slave, Toussaint L'Ouverture. But Napoleon sent General Leclerc to put the island in order.

Then he sent his emissaries to New Orleans to set the Indian tribes against the western settlers, while he organized a military expedition to sail for the delta of the Mississippi. If he could seize the mouth of the river and 
close it to traffic, all the west would fall into his hands. He boasted to his brother Joseph: "In two years we shall be masters of the world."

Slowly, as news traveled over the Wilderness road, these moves became known to every cracker-barrel forum in Kentucky and Ohio. The people knew what it meant, and they didn't propose to put up with it. The militia drilled. A Kentucky expedition was preparing to start for New Orleans even before it was learned what the federal government proposed to do.

President Jefferson was in a quandry. A man of peace, he had opposed the demand of Alexander Hamilton that we take New Orleans by force, and now he strove to restrain the westerners from violence.

Jefferson saw one slim chance of averting war. Perhaps Napoleon might be content with the rest of the vast Territory of Louisiana and would let us buy New Orleans. It was worth trying. He got congress to appropriate the immense sum of $\$ 2,000,000$ and sent an urgent dispatch to Livingston in Paris: Buy New Orleans-and West Florida too if you can.

Livingston put his case to Talleyrand. With all the persuasion he could muster he tried to talk down the value of New Orleans: "An insignificant city set in the wilderness ... only barren sands and sunken marshes ... a small town built of wood ... seven thousand souls."

Talleyrand, with his poker face, merely looked at him.

Meantime, ominous news came from the west. The right of deposit at New Orleans had been ended. Freight piled up on the quays. The westerners hastened their preparations for war.

It was the spring of 1803 . The garden in the Rue Chaussee d'Antin was turning green but Livingston took no pleasure in it. He saw only war and catastrophe ahead.

On April 11, Livingston had one more interview with Talleyrand. Again he went over the old arguments. Again Talleyrand listened in silence. Then suddenly the Frenchman looked Livingston straight in the eye. "What will you give for the whole of Louisiana?" 
The American was too stunned to answer. He had been sent to buy a little town and a narrow strip of coast. Now he was offered half a continent. He had been authorized by congress to spend $\$ 2,000,000$. How much was involved now he could only guess.

Livingston had to make the decision himself. To consult the president would take weeks. Regaining his poise, he might have been a Connecticut horse trader at a fair as he said, "I suppose we should not object to twenty million francs." In American money that was about $\$ 4,000,000$.

Of course Talleyrand said it was far too little. But when they parted the purchase itself had been decided. It remained only to bargain over the amount.

Why did Napoleon make the offer? That has been one of the riddles of history. But it may well have been because his whole plan of conquering the New World was in jeopardy.

The French expedition under Leclerc had defeated the Santo Domingo blacks in battle and by treachery had captured their leader, Toussaint. But this didn't end the revolt. There were disquieting dispatches from Leclerc about guerrilla warfare and the terrific mortality of the French troops from Yellow fever. Then came the dispatch of January 1803. Leclerc was dead. His troops were demoralized, almost annihilated.

It was plain to Napoleon that Santo Domingo was lost. He decided to abandon his western adventure and attack England, using for the new expedition the money he got for Louisiana. And thus it happened that Louisiana was offered to the astonished Livingston.

James Monroe, Jefferson's special envoy, arrived in Paris. He had been dispatched to assist Livingston in protecting American interests after the right of deposit had been revoked. To Livingston's vast relief Monroe agreed that the decision had been right. They joined forces in the bargaining that followed.

Both sides were in a completely illegal position. The Americans had no authority from congress or the con- 
stitution to buy Louisiana. Talleyrand and Napoleon (not yet confirmed in his dictatorial powers) had no authority to sell it.

Nevertheless, the bargaining proceeded. Talleyrand represented his principal as being quite indifferent to the sale. In fact, he intimated, Napoleon was already thinking better of the offer. There was just enough truth in this to make the last days of April a critical period for the U. S. A. Napoleon was about to have himself declared emperor. Meanwhile he had to be careful not to put too much strain on his prestige with the people. How would they react to the loss of both Santo Domingo and Louisiana?

Napoleon's brothers, Joseph and Lucien, were resolved to dissuade him from selling Louisiana. They came to see him one morning, so early that he was still in his bath. The room was full of steam and perfume. It was an unfortunate setting for a business conference.

Joseph and Lucien argued well, and at another time might have succeeded. But Napoleon was in a state of exalted self-confidence. The night before he had been to the Comedie Francaise and had received a wild ovation. So this morning, as he steamed happily, he was pretty sure that he could go as far as he liked with the people and the constitution.

At last Joseph lost his temper. He advanced threateningly to the tub: "If necessary I will put myself at the head of the opposition." Napoleon laughed at him. Joseph, red with anger, cried, "Laugh, laugh then. I will act up to my promise."

Napoleon flew into a rage: "You are insolent!" he shouted. He rose up in the bath, quivering with fury, then threw himself violently back, deluging Joseph with hot, perfumed water. Thereafter no one successfully opposed Napoleon's resolve to sell Louisiana.

After much bargaining a price was agreed upon$\$ 15,000,000$. Livingston and Monroe put their names to the treaty. They must have shivered a little as they did 
so. They had signed away a sum greater than the entire annual revenue of the United States.

They needn't have worried. The president and the congress endorsed the purchase with enthusiasm. Jefferson, it is true, was concerned because he could find no warrant for it in the constitution. Yielding to his advisers, however, he reluctantly gave his approval, "confiding," as he said, "in the good sense of the people."

In New Orleans the crowds cheered when the "Stars and Stripes" went up on the Cabildo. Again the flatboats came crowding down the river on the spring floods.

Napoleon spent every dollar that he received in preparing his expedition against England. Nothing came of it. His legions never crossed the channel; his invasion barges rotted away on the beach at Boulogne.

In the years that followed, the United States began to realize what a vast and rich domain Livingston had bought. Jefferson sent Lewis and Clark to the Northwest, Zebulon Pike to the southwest. Their reports laid the foundation for the great migration across the Mississippi and the unfolding of all the mighty empire of the west. By taking advantage of a lucky break, Livingston achieved what Henry Adams called the greatest diplomatic success in American history.

Livingston's $\$ 15,000,000$ gamble brought us : an area four times the size of France, where 18,000,000 Americans now live. This vast territory produces annually some $3,000,000$ bales of cotton, a billion and a half bushels of corn and wheat, 400,000,000 barrels of oil and minerals worth $\$ 840,000,000$. Its cattle and hogs have a farm value of $\$ 2,000,000,000$. Its principal city, St. Louis, manufactures products worth $\$ 1,000,000,000$ a year. 
Copyright of Annals of Iowa is the property of State of Iowa, by \& through the State Historical Society of Iowa and its content may not be copied or emailed to multiple sites or posted to a listserv without the copyright holder's express written permission. However, users may print, download, or email articles for individual use. 